\title{
Psychometric Properties of the Turkish Version of Prolapse and Incontinence Knowledge Questionnaire
}

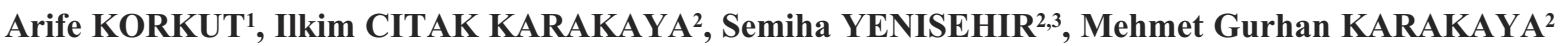 \\ Antalya, Turkey
}

\section{ABSTRACT}

OBJECTIVE: This study aimed to translate and culturally adapt the prolapse and incontinence knowledge questionnaire into Turkish, and to investigate the psychometric properties of the Turkish version prolapse and incontinence knowledge questionnaire.

STUDY DESIGN: Psychometric properties of the Turkish version prolapse and incontinence knowledge questionnaire, which was developed according to standard scientific translation procedures, were analyzed on 206 volunteer women (31.79 \pm 8.79 -year-old), after being tested for its comprehensibility and content validity. The participants were questioned about their physical and socio-demographic characteristics, obstetrical-gynecological histories and menstrual states, current medical complaints, and reasons for applying to the clinics. In addition to Turkish version prolapse and incontinence knowledge questionnaire, they completed the Turkish incontinence quiz, global pelvic floor bother questionnaire, pelvic floor distress inventory-20 and pelvic floor impact questionnaire. Retests were performed on 27 participants, after one week. Internal consistency, test-retest reliability, and construct validity of the Turkish version prolapse and incontinence knowledge questionnaire were investigated.

RESULTS: Internal consistencies of the Turkish version prolapse and incontinence knowledge questionnaire subscales (Turkish version prolapse and incontinence knowledge questionnaire-UI and Turkish version prolapse and incontinence knowledge questionnaire-pelvic organ prolapse) were high (Cronbach $\alpha=0.754$ for both); item-total correlations were $0.127-0.576$ and 0.217-0.509, respectively. Also, test-retest reliabilities of the subscales and the overall scale were high (Intraclass correlation coefficient $=0.949,0.911$ and 0.878 , respectively). Turkish version prolapse and Incontinence knowledge questionnaire scores were highly correlated with incontinence quiz scores and weakly correlated with pelvic floor distress inventory-20 and pelvic floor impact questionnaire-7 scores $(p<0.05)$.

CONCLUSION: It was concluded that Turkish version prolapse and incontinence knowledge questionnaire is a reliable and valid tool to measure Turkish women's knowledge and awareness about urinary incontinence and pelvic organ prolapse.

Keywords: Awareness, Knowledge, Pelvic floor dysfunction, Women's health

Gynecol Obstet Reprod Med 2021;27(2):154-162

\footnotetext{
${ }^{1}$ Cagdas Vefa Private Education and Rehabilitation Center, Antalya, Turkey

2 Mugla Sitki Kocman University, Faculty of Health Sciences, Department of Physiotherapy and Rehabilitation, Mugla, Turkey

${ }_{3}^{3}$ Mus Alparslan University, Department of Physiotherapy and Rehabilitation, Mus, Turkey

Address of Correspondence: Ilkim Citak Karakaya

Mugla Sitki Kocman University, Faculty of

Health Sciences, Department of

Physiotherapy and Rehabilitation, 48000, Mugla-Turkey

ilkim74@yahoo.com
}

Submitted for Publication: 27.04.2020 Revised for Publication:17.05.2020 Accepted for Publication: 17.06.2020 Online Published: 02.08.2021

ORCID IDs of the authors: $\quad$ AK: 0000-0003-0146-5443

ICK: 0000-0003-0233-4533 SY: 0000-0002-3928-2207

MGK: 0000-0002-2395-649X

\begin{tabular}{c|c}
\hline $\begin{array}{c}\text { Quick Response Code: } \\
\text { A }\end{array}$ & Access this article online \\
\cline { 2 - 2 } & $\begin{array}{l}\text { Website: www.gorm.com.tr } \\
\text { e- mail: info@gorm.com.tr }\end{array}$ \\
\cline { 2 - 2 } & DOI:10.21613/GORM.2020.1099 \\
\hline
\end{tabular}

\section{Introduction}

Urinary incontinence (UI) and pelvic organ prolapse (POP) are common symptoms of pelvic floor dysfunction (PFD) and have negative impacts on women' quality of life by causing physical discomfort, social complications, economic losses, and embarrassment $(1,2)$. The incidence of UI is $13 \%$ at a young age, $35 \%$ in middle and advanced ages in women, and this rate increases during pregnancy and postpartum $(3,4)$. In Turkey, the percentage of women with UI complain was reported as $23.9-49.5 \%(5,6)$. POP is another common gynecological problem with a prevalence of $30-50 \%$ in women over the age of 50 and occurs due to weakness or damage of the supportive tissues of the pelvis such as muscles and ligaments (7-9).

How to cite this article: Korkut A. Citak Karakaya I. Yenisehir S. Karakaya MG. Psychometric Properties of the Turkish Version of Prolapse and Incontinence Knowledge Questionnaire. Gynecol Obstet Reprod Med. 2021; 27(2): $154-162$ 
Pelvic floor muscles play an important role in sexual function by providing bladder and bowel control $(10,11)$. Weakened or damaged muscles may lead to PFD symptoms such as urinary and fecal incontinence, POP, sexual dysfunction, pelvic pain, and constipation $(8,10,11)$. It has been reported that $77 \%$ of patients with sexual, urinary, or gastrointestinal symptoms also have pelvic floor muscle dysfunction (10).

In a research conducted by the International Continence Society in 2003, it was shown that there is a lack of knowledge and awareness about urinary stress incontinence, which is the most common type of incontinence in women (8). The World Health Organization (WHO) has named UI as one of the "latest medical taboo". In some countries, large-scale studies have been conducted towards the awareness of PFD, and it is emphasized that awareness of this preventable and treatable medical problem should be raised $(12,13)$.

Because of their insufficient knowledge and awareness about pelvic floor health, many women remain silent about this issue and do not seek a solution, even if they have PFD symptoms $(8,14)$. However, many forms of PFD are preventable, and considering it as a public health problem may improve knowledge and awareness both in the community and among health professionals (15). It is very important to evaluate women's knowledge and attitudes about PFD before the symptoms get worse and deteriorate the quality of life, so that, healthcare professionals can avoid delays in seeking treatment.

Reliable and valid tools for assessing knowledge and awareness about PFD are limited in number and generalizability. Prolapse and incontinence knowledge questionnaire (PIKQ) is one of these tools and is composed of two subscales, each with 12 items: PIKQ-UI and PIKQ-POP. It has previously been used to assess PFD knowledge and awareness of women in fertile age office-workers and women from different races $(8,16,17,18)$.

At the start date of this study, the only published reliable and valid Turkish tool for assessing knowledge about PFD was the incontinence quiz (IQ), which intended for just UI. Since the PIKQ was a measure assessing knowledge about not only UI but also POP, this study aimed to cross-culturally adapt it into Turkish and to investigate the psychometric properties such as test-retest reliability, internal consistency, content validity and construct validity on outpatients of obstetrics and gynecology clinics.

\section{Material and Method}

After obtaining permission from the developers of the original scale (Shah AD, e-mail date: 08.08.2017) to translate and culturally adapt the PIKQ into Turkish, Human Research Ethical Board of the Mugla Sitki Kocman University (date: 22.11.2017, approval no: 170036) and General Secretary of the Association of Public Hospitals in Antalya Province (date: 26.09.2017, document no: 52415545-604.02) has approved the study in ethical and administrative aspects, respectively. The study was conducted under the Declaration of Helsinki, and all participants have signed an informed consent form before enrollment.

\section{Translation Procedure}

Standard scientific translation and cross-cultural adaptation guidelines by Guillemin et al. (1993) and Beaton et al. (2000) were followed for this study $(19,20)$. The original PIKQ was translated into Turkish by two bilingual translators, independently. These translations were analyzed and synthesized by a committee composed of the authors and two other academicians, by addressing and resolving the conflicting phrases of the two independent translations. To be more comprehensible for Turkish speaking women, an explanation for "pelvic heaviness and/or pressure" in the 5th item of the PIKQ-POP was added to the Turkish version ("pelvik (alt tarafta) ağırlık ve/veya basınç hissini"). After reaching a consensus on a common draft, this was back-translated into English by a native speaker. The back-translator was an English instructor, had no medical background, and was blinded to the original version. After the back-translation procedure, an expert committee composed of bilingual translators, other authors, and physiotherapist academicians confirmed the equality of the original and Turkish versions of the PIKQ.

Following these translation and back-translation procedures, comprehensibility of the scale items was tested on 20 women patients, using a 4-point Likert scale (1=not comprehensible, $4=$ completely comprehensible). The ratio of items rated as 3 or 4 was 0.77 and indicated that the Turkish version (TrPIKQ) was quite comprehensible. To analyze the content validity of the scale, a professional group composed of 10 women's health physiotherapists and gynecologists were asked to rate the relevance of the scale items on a 4-point Likert scale ( $1=$ not relevant, $4=$ completely relevant). The content validity index of the scale was calculated as 0.95 , indicating that the scale had a strong content validity $(21,22)$.

\section{Sample Size Calculation and Participants}

By using $\mathrm{G}^{*}$ Power 3.1 software $(r=0.30$ for moderate and two-tailed correlations, alpha level $=0.01$ and power level $=95 \%$ ), a sample size of at least 189 participants was calculated.

The participants were the outpatients of obstetrics and gynecology departments of two public hospitals in Antalya province. After interviewing with 319 patients, 206 women who met the inclusion criteria and signed the informed consent were included in this study (Figure 1). The inclusion criteria were: being above 18 years; applying as an outpatient to the relevant institutions; and reading, writing, and communicating in Turkish. The patients who had PFD with a neurological origin were excluded. 

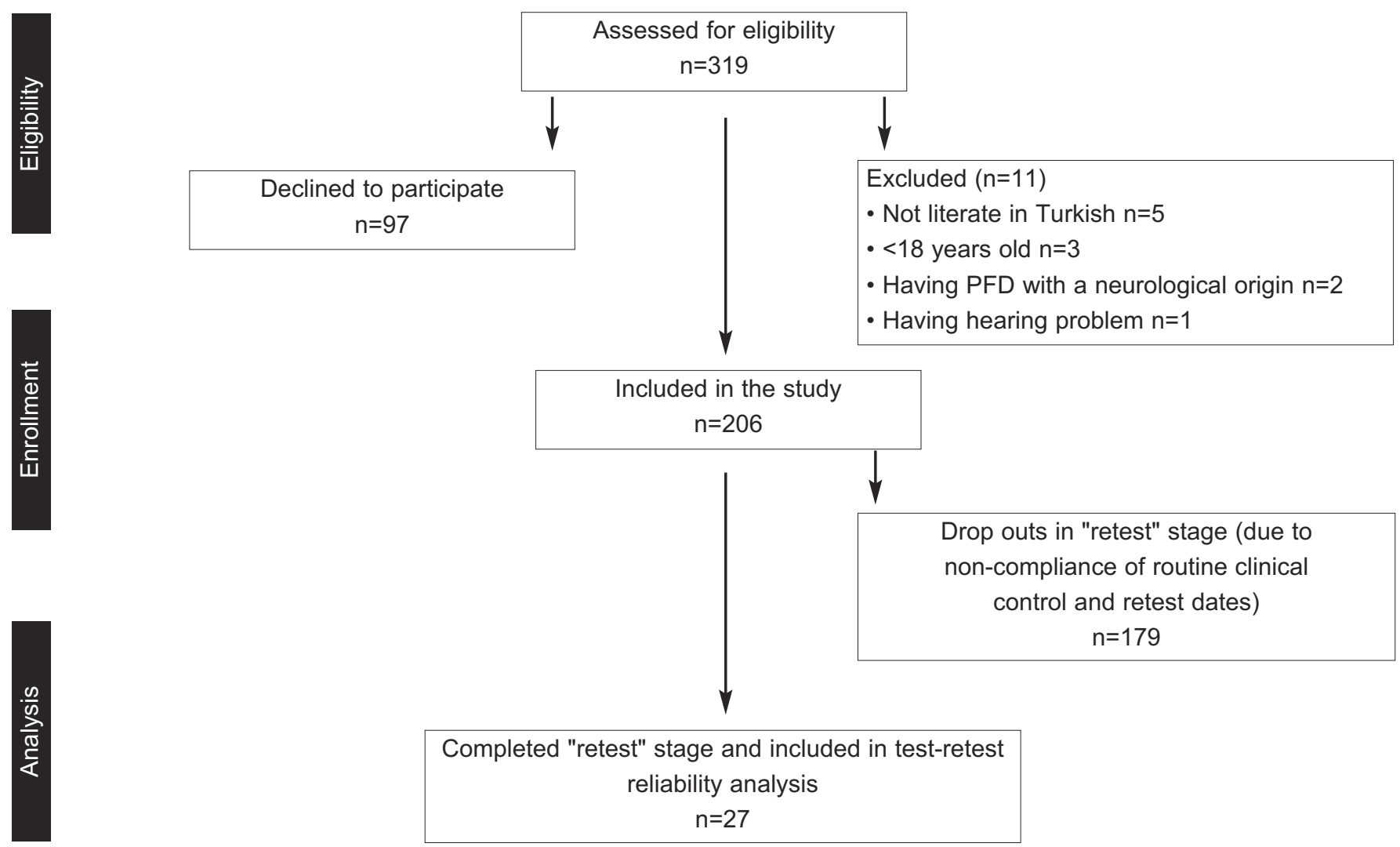

Figure 1: Flow chart of participants

\section{Assessments}

The participants were questioned about their physical and socio-demographic characteristics; obstetrical-gynecological histories and menstrual states; current medical complaints and reasons for applying to the clinics. They were also asked to complete the following questionnaires:

Turkish prolapse and incontinence knowledge questionnaire: The participants read and indicated their agreement levels (agree, disagree, do not know) with 24 items (12 items for each subscale) in this knowledge scale. As shown in the Appendix, each item has a correct response, and the participants were given a "1" point if they have marked that response. Incorrect, missing, or "don't know" were scored as "0" points (Appendix). Scores of subscales (0-12 points), and the overall scale ( $0-24$ points) were calculated, and higher scores indicated a higher level of knowledge $(23,24)$. For the retest purpose, the scale was re-rated by the participants after one week.

Incontinence quiz: This tool, which was developed by Branch et al. to assess UI knowledge, was shown to be reliable and valid for use in Turkish gynecology patients by Kara et al. (2017) $(25,26)$. This 14-item self-administered scale was filled by the participants, marking each item as "Agree/ Disagree/ Don't know". The correct responses were given " 1 " point ("Agree" for the $1^{\text {st }}, 4^{\text {th }}, 6^{\text {th }}, 8^{\text {th }}, 10^{\text {th }}, 11^{\text {th }}$ items; and "Disagree" for the $2^{\text {nd }}, 3^{\text {rd }}, 5^{\text {th }}, 7^{\text {th }}, 9^{\text {th }}, 12-14^{\text {th }}$ items), and "Don't know" responses were given " 0 " point. The total score of the scale is 0 14 and higher scores indicate a higher knowledge level (26).
Global pelvic floor bother questionnaire: Turkish GPFBQ is a reliable and valid symptom questionnaire used for assessment of the severity of and bother due to various pelvic floor symptoms, and has nine questions with "yes/no" response options (27). For questions answered as "yes", the extent of bother is graded on a 5-point Likert scale ( $1=$ "not at all" - 5= "a lot"). The total score is between 0 and 45 , and for a $0-100$ score range, item scores are multiplied by 20 . To obtain the average score, nine domain scores are summed and divided by 9 . Higher scores indicate that the complaint is severe (27).

Pelvic floor distress inventory-20: This questionnaire has three subscales for UI, POP, and Colo-Rectal-Anal distress, to evaluate all symptoms and severity of PFDs. Each item of the scale is scored as "no $=0$ " or "yes $=1$ ". For items with "yes", the symptom severity is graded as " $1=$ unimportant $-4=\mathrm{a}$ lot". Subscale and total scale scores range between 0-100 and 0-300, respectively; and higher scores indicate more severe PFD (28).

Pelvic floor impact questionnaire-7: This scale, consisting of seven questions in three subscales for UI, POP, and Colorectal-anal impact, was used to evaluate the impact of PFDs on quality of life. All items are graded as " $0=$ not at all$3=$ quite a bit. Total scores of the subscales and the overall scale range between 0 (least)-100 (greatest) and 0 (least)-300 (greatest), respectively (29).

\section{Statistical analysis}

Data were analyzed by Statistical Package for the Social Sciences (SPSS version 24.0 for MAC). The intraclass correla- 
tion coefficient (ICC) and 95\% confidence intervals (CI) were used for test-retest reliability. ICC values $<0.50,0.50$ to 0.75 , 0.75 to 0.90 and $>0.90$ were considered as poor, moderate, good, and excellent reliability, respectively (30). The internal consistency of the subscales was analyzed by Cronbach's $\alpha$ coefficient and item-total correlations. Cronbach's $\alpha$ coefficients $>0.80$ were interpreted as "high", $0.60-0.79$ as "moderate" and $0.40-0.59$ as "low" reliability. To investigate the construct validity of the PIKQ and subscales, their correlations with the IQ was analyzed. Spearman's test was also used for analyzing correlations of PIKQ with other scales (GPFBQ, PFIQ-7, and PFDI-20). Correlations were interpreted as high $(r>0.60)$, moderate $(r=0.30-0.59)$ or low $(r<0.29)(22,26,31-33)$.

\section{Results}

The age of 206 participants ranged between 18-78 years, and most of them were at reproductive age. More than half were married and housewives and had an educational level under the university. The physical and sociodemographic characteristics of the subjects are presented in table I.

Table I: Physical and sociodemographic characteristics of the subjects

\begin{tabular}{|c|c|}
\hline$n=206$ & Mean \pm SD \\
\hline \multicolumn{2}{|l|}{ Physical characteristics } \\
\hline Age (year) & $31.79 \pm 8.79$ \\
\hline Height $(\mathrm{cm})$ & $165.32 \pm 6.07$ \\
\hline Weight (kg) & $70.55 \pm 10.98$ \\
\hline BMI $\left(\mathrm{kg} / \mathrm{m}^{2}\right)$ & $25.88 \pm 4.24$ \\
\hline Sociodemographic characteristics & n (\%) \\
\hline \multicolumn{2}{|l|}{ Education } \\
\hline Primary school & $32(15.5)$ \\
\hline Secondary school & $25(12.1)$ \\
\hline High school & $63(30.6)$ \\
\hline University & $86(41.8)$ \\
\hline \multicolumn{2}{|l|}{ Occupation } \\
\hline Housewife & $106(51.5)$ \\
\hline Office worker & $13(6.3)$ \\
\hline Worker & $30(14.6)$ \\
\hline Teacher & $13(6.3)$ \\
\hline Health professional & $23(11.2)$ \\
\hline Student & $9(4.4)$ \\
\hline Self-employed & $12(5.8)$ \\
\hline \multicolumn{2}{|l|}{ Marital Status } \\
\hline Married & $161(78.2)$ \\
\hline Single & $35(17.0)$ \\
\hline Widow/divorced & $10(4.9)$ \\
\hline
\end{tabular}

\footnotetext{
According to obstetrical histories, $20.4 \%$ of women were nulliparous and $26.3 \%$ had three or more pregnancies. The vaginal birth rate was $45.6 \%$ and the Cesarean section rate was low (18.4\%). The percentage of women having more than three children (7.3\%), D\&C (4.9\%) and abortion (9.7\%) histories were also low. Only $20.4 \%$ of the participants reported a surgery history (Cesarean, appendectomy, cervical stenosis, etc).
}

$59.2 \%$ of subjects were pregnant, $24.3 \%$ had regular menstruation, $10.2 \%$ had irregular menstruation, and $6.3 \%$ were in menopause. The percentage of women with UI, POP, and constipation complaints was $34.5 \%, 6.3 \%$, and $21.4 \%$, respectively. None of them had fecal incontinence.

Table II presents the mean number of correct responses for the subscales and overall PIKQ scale. The percentage of correct responses was calculated as (number of correct responses/12) *100 for the subscales, and (number of correct responses/24) $* 100$ for the overall scale (34). Therefore, the participants correctly responded to $68.04 \%$ of the overall scale; $76.70 \%$ of the UI; and $59.94 \%$ of the POP subscales. Besides, based on the suggestions by the developer of the scale, $\geq 80 \%$ correct responses in PIKQ-UI, and $\geq 50 \%$ correct responses in PIKQ-POP scales were considered as knowledge proficiency (18). According to that classification, $42.7 \%(n=88)$ and $24.3 \%(n=50)$ of the subjects had a lack of knowledge about UI and POP, respectively. The mean number of correct responses in TrPIKQ and IQ questionnaires, as well as the mean scores of other questionnaires, are presented in table II.

Table II. The scores of Turkish prolapse and incontinence knowledge questionnaire, incontinence quiz, global pelvic floor bother questionnaire, pelvic floor distress inventory-20, and Pelvic floor impact questionnaire-7

\begin{tabular}{|c|c|c|}
\hline$n=206$ & Mean $\pm S D$ & $\begin{array}{c}\text { Total score } \\
\text { min-max }\end{array}$ \\
\hline Incontinence Quiz & $7.9 \pm 2.8$ & $1-14.0$ \\
\hline $\begin{array}{l}\text { Global pelvic floor bother } \\
\text { questionnaire }\end{array}$ & $16.6 \pm 12.8$ & $0-77.8$ \\
\hline Pelvic floor distress inventory-20 & $28.0 \pm 31.9$ & $0-208.3$ \\
\hline POPDI-6 & $11.1 \pm 13.4$ & $0-70.8$ \\
\hline UDI-6 & $12.5 \pm 16.2$ & $0-87.5$ \\
\hline CRADI-8 & $4.4 \pm 8.4$ & $0-59.4$ \\
\hline Pelvic floor impact questionnaire-7 & $12.2 \pm 22.5$ & $0-128.6$ \\
\hline UIQ-7 & $7.7 \pm 12.9$ & $0-66.7$ \\
\hline CAIQ-7 & $3.6 \pm 9.8$ & $0-66.7$ \\
\hline POPIQ-7 & $0.9 \pm 4.7$ & $0-33.3$ \\
\hline $\begin{array}{l}\text { Prolapse and incontinence } \\
\text { knowledge questionnaire }\end{array}$ & $16.3 \pm 4.9$ & $1-24$ \\
\hline PIKQ-UI & $9.2 \pm 2.6$ & $1-12$ \\
\hline PIKQ-POP & $7.2 \pm 2.7$ & $0-12$ \\
\hline
\end{tabular}

POPDI-6: Pelvic organ prolapse distress inventory-6, CRADI-8: Colorectal-anal distress inventory-8, UDI-6: Urinary distress inventory-6, UIQ: Urinary impact questionnaire; POPIQ: Pelvic organ prolapse impact questionnaire, CAIQ: Colorectal-anal impact questionnaire, PIKQUI: Prolapse and Incontinence knowledge questionnaire-urinary incontinence, PIKQ-POP: Prolapse and incontinence knowledge questionnaire-pelvic organ prolapse

\section{Internal consistency}

Cronbach's $\alpha$ values of both subscales were 0.754 and indicated high internal consistency. Item-total correlations were between $\mathrm{r}=0.127$ and $r=0.576$ for the UI; and between $r=0.217$ and $r=0.509$ for the POP subscales. The second item in the UI subscale and the first item in the POP subscale had the lowest item-total correlations ( $r=0.127$ and 0.217 , respectively). Deleting these items resulted in similar Cronbach's $\alpha$ values ( 0.761 and 0.758 , respectively), indicating that they had no significant effect on internal consistency (Table III). 
Table III: Item analysis of Turkish prolapse and incontinence knowledge questionnaire-urinary incontinence and Turkish prolapse and incontinence knowledge questionnaire-pelvic organ prolapse

\begin{tabular}{lcccc} 
Items & Items total correlation $(r) \quad$ Cronbach $\alpha$ if item deleted & Items total correlation $(r)$ & Cronbach $\alpha$ if item deleted \\
\hline \multicolumn{3}{c}{ TrPIKQ-UI } \\
\hline 1 & 0.217 & 0.757 & 0.217 & 0.758 \\
2 & 0.127 & 0.761 & 0.343 & 0.744 \\
3 & 0.381 & 0.739 & 0.441 & 0.731 \\
4 & 0.423 & 0.735 & 0.509 & 0.722 \\
5 & 0.445 & 0.731 & 0.364 & 0.742 \\
6 & 0.492 & 0.724 & 0.455 & 0.733 \\
7 & 0.320 & 0.747 & 0.449 & 0.732 \\
8 & 0.576 & 0.716 & 0.382 & 0.739 \\
9 & 0.424 & 0.733 & 0.461 & 0.732 \\
10 & 0.535 & 0.719 & 0.322 & 0.745 \\
11 & 0.217 & 0.762 & 0.278 & 0.749 \\
12 & 0.569 & 0.718 & 0.486 & 0.726
\end{tabular}

TrPIKQ-UI: Turkish prolapse and incontinence knowledge questionnaire-urinary incontinence, TrPIKQ-POP: Turkish prolapse and incontinence knowledge questionnaire-pelvic organ prolapse

\section{Test-retest reliability}

Test-retest reliability of the TrPIKQ was analyzed on 27 participants, who re-rated the scale one week after the first assessment. ICC and 95\% CI values showed high and significant correlations between the test and retest conditions, for both subscales and the overall scale (Table IV).

Table IV: Test-retest reliability of Turkish prolapse and incontinence knowledge questionnaire, Turkish prolapse and incontinence knowledge questionnaire-urinary incontinence, and Turkish prolapse and incontinence knowledge questionnairepelvic organ prolapse

\begin{tabular}{|c|c|c|c|}
\hline$n=27$ & & ICC & $95 \% \mathrm{Cl}$ \\
\hline \multirow[t]{3}{*}{ TrPIKC } & & 0.878 & $0.521-0.956$ \\
\hline & $\begin{array}{l}\text { Urinary incontinence } \\
\text { (TrPIKQ-UI) }\end{array}$ & 0.949 & $0.846-0.980$ \\
\hline & $\begin{array}{l}\text { Pelvic Organ Prolapse } \\
\text { (TrPIKQ-POP) }\end{array}$ & 0.911 & $0.506-0.971$ \\
\hline
\end{tabular}

ICC: Intraclass correlation coefficient (relative reliability); Cl: Confidence interval. TrPIKQ: Turkish prolapse and incontinence knowledge questionnaire, UI: Urinary incontinence POP: Pelvic organ prolapse

\section{Construct validity}

A positive moderate-high correlation between the scores of TrPIKQ and IQ $(p<0.05)$ indicated that the scale had good construct validity. The scores of TrPIKQ had no correlations with GPFBQ $(p>0.05)$ and had a negative and poor correlation with PFDI-20 and its UDI-6 subscale $(p<0.05)$. Also, TrPIKQ and TrPIKQ-UI scale scores were in negative and poor correlation with PFIQ-7 and UIQ-7 subscales $(p<0.05)$ (Table V).

\section{Discussion}

The findings of the study show that the TrPIKQ has adequate psychometric properties for use in the assessment of UI and POP knowledge. Mean age, sociodemographic characteristics, obstetric history, and menstrual status of participants were similar to the previous studies which focused on the knowledge and awareness related to PFD $(8,26,35)$.

Table V. The construct validity and correlations of Turkish prolapse and incontinence knowledge questionnaire and subscales

\begin{tabular}{|c|c|c|c|c|}
\hline \multicolumn{2}{|l|}{$n=206$} & $\begin{array}{c}\text { TrPIKQ-UI } \\
r(p)\end{array}$ & $\begin{array}{c}\text { TrPIKQ-POP } \\
r(p)\end{array}$ & $\begin{array}{c}\operatorname{TrPIKQ} \\
r(\mathrm{p})\end{array}$ \\
\hline \multirow{3}{*}{\multicolumn{2}{|c|}{$\begin{array}{l}\text { IQ } \\
\text { GPFBQ } \\
\text { PFDI-20 }\end{array}$}} & $0.634(0.000)^{* *}$ & $0.475(0.000)^{* *}$ & $0.596(0.000)^{* *}$ \\
\hline & & $-0.090(0.199)$ & $-0.088(0.209)$ & $-0.098(0.162)$ \\
\hline & & $-0.178(0.010)^{\star *}$ & $-0.149(0.033)^{*}$ & $-0.172(0.013)^{*}$ \\
\hline & POPDI-6 & $-0.098(0.159)$ & $-0.032(0.649)$ & $-0.072(0.301)$ \\
\hline & UDI-6 & $-0.202(0.004)^{\star *}$ & $-0.199(0.004)^{\star *}$ & $-0.210(0.002)^{*}$ \\
\hline & CRADI-8 & $-0.097(0.167)$ & $-0.084(0.229)$ & $-0.098(0.163)$ \\
\hline \multirow[t]{4}{*}{ PFIQ-7 } & & $-0.191(0.006)^{\star \star}$ & $-0.103(0.142)$ & $-0.145(0.037)^{*}$ \\
\hline & UIQ-7 & $-0.206(0.003)^{\star *}$ & $-0.121(0.082)$ & $-0.164(0.019)^{\star}$ \\
\hline & CAIQ-7 & -0.037 (0.599) & $0.015(0.834)$ & $-0.004(0.958)$ \\
\hline & POPIQ-7 & $-0.004(0.949)$ & $0.106(0.131)$ & $0.073(0.300)$ \\
\hline
\end{tabular}

${ }^{*} p<0.05,{ }^{* *} p<0.01$. TrPIKQ-UI: Turkish prolapse and incontinence knowledge questionnaire urinary incontinence, TrPIKQ-POP: Turkish prolapse and incontinence knowledge questionnaire - Pelvic organ prolapse, IQ: Incontinence Quiz,GPFBQ: Global pelvic floor bother questionnaire, PFDI-20: Pelvic Floor Distress Inventory-20, POPDI-6: Pelvic organ prolapse distress inventory-6, UDI-6: Urinary distress inventory-6, CRADI-8: Colo-rectalanal distress inventory-8, PFIQ-7: Pelvic Floor Impact Questionnaire, CAIQ: Colorectal-anal impact questionnaire, POPIQ-7: Pelvic Organ Prolapse Impact Questionnaire-7 
Relevancy ratings of the scale items by women's health physiotherapists and gynecologists showed that the content validity index of the TrPIKQ was 0.95 , indicating that this scale was suitable for the purpose and had content validity $(21,22)$.

During the planning and data collection phases of this study, there was not any published language version of the original PIKQ, except German and Russian of a modified PIKQ-POP version. This modified scale was developed by Lyatoshinskaya et al. (2016), by adding four more questions to the original English version of PIKQ-POP (35). Following the data collection phase, it was noticed that another Turkish version of the scale was recently published (24).

In their study investigating the POP knowledge of German and Russian urogynecology patients, Lyatoshinskaya et al. (2016) have analyzed 110 questionnaires for German and 95 questionnaires for Russian versions (35). They have stated that the 17-item modified German PIKQ-POP had good $\left(\mathrm{x}^{2}=138.921\right)$, but the modified Russian PIKQ-POP had poor $\left(x^{2}=153.07\right)$ model fits. By removing the 13th item from both language versions, they have found that 16-item German and Russian modified PIKQ-POP subscales had an acceptable internal consistency (Cronbach $\alpha=0.782$ and 0.667 , respectively). In a study by Toprak Çelenay et al. (2019), the previous Turkish versions of both subscales were also found to have good internal consistency (KR-20 $=0.67$ and 0.75 , respectively) (24). Though being analyzed with different statistical methods, it can be said that the internal consistency of the current TrPIKQ-UI (Cronbach $\alpha=0.754$ ) is higher than the previous Turkish version. Also, the internal consistency of the current TrPIKQ-POP (Cronbach $\alpha=0.754$ ) is similar to the German and previous Turkish versions, and higher than the Russian version.

The high ICC values in this study showed that the TrPIKQ-UI (0.949) and TrPIKQ-POP (0.911) had excellent test-retest reliability. This psychometric property was not investigated for the German and Russian PIKQ-POP scales (35), and the previous Turkish version had slightly lower ICC values $(\mathrm{ICC}=0.91-0.90)$, indicating that the stability of the current version is higher (24).

The construct validity of the TrPIKQ and subscales was analyzed by correlation analysis with the IQ scores. In the original study, the construct validity of both scales was examined by using principal component analysis and comparison of total UI and POP scale scores with a double-tailed t-test (18). The IQ was preferred for determining the construct validity because the scale measures the level of UI knowledge. Since there is not any previous reliable and valid Turkish scale that assesses the level of knowledge about POP; and that, both UI and POP are concepts gathered under the roof of PFD, the construct validity of PIKQ-POP was also utilized from the IQ scores. The IQ scores were found to be highly correlated with TrPIKQ-UI and overall TrPIKQ scores ( $r=0.634$ and 0.596 , respectively), and moderately correlated with TrPIKQ-POP scores $(r=0.475)$.
Toprak Celenay et al. (2019) have also used the correlations with IQ to examine the construct validity and showed a moderate correlation $(\mathrm{rho}=0.679)$ between the PIKQ-UI and IQ scores. These findings point out that both Turkish translation versions are reliable and valid, and adequate for use in measuring the level of knowledge about UI and POP (24).

Besides, correlations of TrPIKQ scores with the GPFBQ, PFIQ-7, and PFDI-20 scores were examined. Although TrPIKQ and its subscales were correlated to some of these scales, the correlation coefficients were very low. This may be because the TrPIKQ (level of knowledge about UI and POP) and other relevant scales assess different concepts (impact on PFD symptoms, severity, and quality of life) related to PFD, and the symptom/impact severity of the study sample is quite low.

Lack of using another reliable and valid Turkish POP knowledge scale for construct validity analysis can be considered as a limitation of this study. Secondly, there was a high dropout rate $(86.89 \%)$ in the retest stage, due to the mismatch of medical appointment and retest dates. Lastly, the data are collected from a single geographical region, and due to the possibility of cultural diversities, the generalizability of the findings for Turkish women living in different geographical regions may be questionable.

\section{Conclusion}

It was concluded that as a reliable and valid scale, clinicians and researchers may use the TrPIKQ to measure knowledge and awareness of Turkish women about UI and POP, as well as to investigate the effectiveness of different strategies towards improving these issues. Other psychometric properties of the scale such as responsiveness should be analyzed in future studies.

Acknowledgment: The authors thank Baki Umut Tŭgay, PT. Ph.D. Prof., Nazan Tuğay, PT. Ph.D. Prof, and Rasheedah Frances Mullings Dağkıran for their support in the translation and back-translation procedures.

Funding: This research (Project Grant Number 19/077/12/3/4 and the title 'Prolaps ve Inkontinans Bilgi Anketinin Türkçe Versiyonu: Kültürel Adaptasyon, Güvenilirlik ve Geçerlilik') has been granted by Mugla Sitki Kocman University Research Projects Coordination Office.

Conflict of Interest: The authors have no conflicts of interest to declare.

Author Contribution: AK: Project development, design, data collection, literature search, analysis/interpretation; IÇK: Project development, design, literature search, analysis/interpretation, writing, supervision; SY: Data collection, literature search, analysis/interpretation, writing; MGK: Design, analysis/interpretation, critical review. 
Prolapse and Incontinence Knowledge Quiz (PIKQ) - Incontinence
Prolaps ve İnkontinans Bilgi Anketi (PIBA) - İnkontinans

No Below are some statements about urinary inconti- Aşağıdakiler, üriner inkontinans (idrar kaçırma) ile nence (loss of urine or leaky bladder). Please ilgili bazı ifadelerdir. Lütfen her bir ifade için katılıp state if you agree or disagree with each statement, katılmadığınızı veya bilmediğinizi belirtin. or if you do not know.

Urinary incontinence (loss of urine or leaky blad- İdrar kaçırma genç kadınlarda, yaşı kadınlardan

der) is more common in young women than in old women.

Women are more likely than men to leak urine.

daha sık görülür.

Kadınların idrar kaçırma intimali erkeklerden daha fazladır.

Other than pads and diapers, not much can be done to treat leakage of urine.

İdrar kaçırmaya karşı ped ve alt bezi kullanmaktan başka yapılabilecek pek bir şey yoktur.

4 It is NOT important to diagnose the type of urine leakage before trying to treat it.

Tedavi etmeye çalışmadan önce idrar kaçırma tipini teşhis etmek önemli DEĞíLDiR.

5 Many things can cause urine leakage.

Birçok şey idrar kaçırmaya neden olabilir.

6 Certain exercises can be done to help to control

Belirli egzersizler idrar kaçırma kontrolüne urine leakage.

yardımcı olması için yapılabilir.

7 Some medications may cause urinary leakage.

Bazı ilaçlar idrar kaçırmaya neden olabilir.

Once people start to leak urine, they are never able to control their urine again.

Insanlar bir kez idrar kaçırmaya başladıklarında idrarlarını bir daha asla kontrol edemezler.

9 Doctors can do special types of bladder testing to diagnose urine leakage

İdrar kaçırmayı teşhis etmek için doktorlar özel mesane testleri yapabilirler.

10 Surgery is the only treatment for urinary leakage.

Ameliyat, idrar kaçırmanın tek tedavisidir.

11 Giving birth many times may lead to urine leakage.

Most people who leak urine can be cured or improved with some kind of treatment.

Çok doğum yapmak idrar kaçırmaya yol açabilir.

İdrar kaçıran kişilerin çoğu bazı tedavilerle tamamen veya kısmen iyileşebilir.

\begin{tabular}{|c|c|c|}
\hline 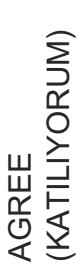 & 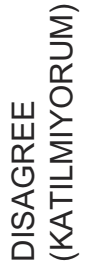 & 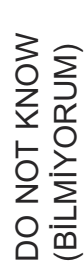 \\
\hline & $x$ & \\
\hline \multirow[t]{3}{*}{$x$} & & \\
\hline & $x$ & \\
\hline & $x$ & \\
\hline$x$ & & \\
\hline$x$ & & \\
\hline \multirow[t]{2}{*}{$x$} & & \\
\hline & $x$ & \\
\hline \multirow[t]{2}{*}{$x$} & & \\
\hline & $x$ & \\
\hline$x$ & & \\
\hline$x$ & & \\
\hline
\end{tabular}

\section{Prolapse and Incontinence Knowledge Quiz (PIKQ) - POP}

No prolapse from getting worse.

5 Symptoms of pelvic organ prolapse may include pelvic heaviness and/or pressure.

6

A good way for a doctor to diagnose pelvic organ prolapse is by examining the patient.

7 Once a patient has pelvic organ prolapse, not much can be done to help her.

8 Heavy lifting on a daily basis can lead to pelvic organ prolapse.

9 Surgery is one type of treatment for pelvic organ prolapse.

10 Doctors can run a blood test to diagnose pelvic organ prolapse.

11 A rubber ring called a pessary can be used to treat symptoms of pelvic organ prolapse.

\section{Prolaps ve İnkontinans Bilgi Anketi (PIBA) - POP}

Aşağıdakiler, pelvik organ sarkması (vajina, rahim, mesane veya makat sarkması) ile ilgili bazı ifadelerdir. Lütfen her bir ifade için katııı katılmadığınızı veya bilmediğinizi belirtin.

a, Pelvik organ sarkması (vajina, rahim, mesane veya makat sarkması) genç kadınlarda, yaşlı kadınlardan daha sıktır.

Çok doğum yapmak pelvik organ sarkmasına yol açabilir.

Pelvik organ sarkması herhangi bir yaşta meydana gelebilir.

Belirli egzersizler pelvik organ sarkmasının kötüleşmesini durdurmaya yardımcı olabilir.

Pelvik organ sarkmasının belirtileri, pelvik (alt tarafta) ağırlık ve/veya basınç hissini içerebilir.

Hastayı muayene etmek, doktorun pelvik organ sarkmasını teşhis etmesinin iyi bir yoludur.

Bir hastada pelvik organlar sarktığında, onun için yapılabilecek pek bir şey yoktur.

Her gün ağır kaldırmak pelvik organ sarkmasına yol açabilir.

Ameliyat, pelvik organ sarkması için tedavi türlerinden biridir.

Doktorlar pelvik organ sarkmasını teşhis etmek için kan testi yapabilirler.

Pelvik organ sarkması belirtilerini tedavi etmek için peser denilen lastik bir halka kullanılabilir.

Obez insanlarda pelvik organ sarkması intimali daha düşüktür.

\begin{tabular}{|c|c|}
\hline & $x$ \\
\hline$x$ & \\
\hline$x$ & \\
\hline$x$ & \\
\hline$x$ & \\
\hline$x$ & \\
\hline & $x$ \\
\hline$x$ & \\
\hline$x$ & \\
\hline & $x$ \\
\hline$x$ & \\
\hline & $x$ \\
\hline
\end{tabular}




\section{References}

1. Haylen BT, De Ridder D, Freeman RM, Swift SE, Berghmans $\mathrm{B}$, Lee $\mathrm{J}$, et al. An International Urogynecological Association (IUGA)/International Continence Society (ICS) joint report on the terminology for female pelvic floor dysfunction. Neurourol Urodyn. 2010;29(1):4-20. Doi: 10.1002/nau.20798.

2. Liao YM, Dougherty MC, Liou YS, Tseng IJ. Pelvic floor muscle training effect on urinary incontinence knowledge, attitudes, and severity: An experimental study. Int J Nurs Stud. 2006;43(1):29-37. doi: 10.1016/j.ijnurstu.2005.01.0 04.

3. Chiarelli P, Brown W, McElduff P. Leaking urine: prevalence and associated factors in Australian women. Neurourol Urodyn. 1999;18(6):567-77. doi: 10.1002/ (sici)1520-6777(1999)18:6<567::aid-nau7>3.0.co;2-f.

4. Chiarelli P, Murphy B, Cockburn J. Women's knowledge, practices, and intentions regarding correct pelvic floor exercises. Neurourol Urodyn 2003;22(3):246-9. doi: 10.10 02/nau.10119.

5. Kocak I, Okyay P, Dundar M, Erol H, Beser E. Female urinary incontinence in the west of Turkey: prevalence, risk factors and impact on quality of life. Eur Urol. 2005; 48(4):634-41. doi: 10.1016/j.eururo.2005.04.017.

6. Tozun M, Ayranci U, Unsal A. Prevalence of urinary incontinence among women and its impact on quality of life in a semirural area of Western Turkey. Gynecol Obstet Invest. 2009;67(4):241-9. doi: 10.1159/000209310.

7. Low LK, Tumbarello JA. Falling out: authoritative knowledge and women's experiences with pelvic organ prolapse. J Midwifery Womens Health. 2012;57(5):489-94.

8. Berzuk K, Shay B. Effect of increasing awareness of pelvic floor muscle function on pelvic floor dysfunction: a randomized controlled trial. Int Urogynecol J. 2015;26 (6):837-44. doi: 10.1007/s00192-014-2599-z.

9. Tehrani FR, Hashemi S, Simbar M, Shiva N. Screening of the pelvic organ prolapse without a physical examination; (a community based study). BMC Womens Health. 2011; 11:48. doi: 10.1186/1472-6874-11-48.

10. Voorham-van der Zalm PJ, Lycklama Â Nijeholt GAB, Elzevier HW, Putter H, Pelger RCM. "Diagnostic investigation of the pelvic floor": a helpful tool in the approach in patients with complaints of micturition, defecation, and/or sexual dysfunction. J Sex Med. 2008;5(4):864-71. doi: 10.1111/j.1743-6109.2007.00725.x.

11. Ashton Miller JA, DeLancey JO. Functional anatomy of the female pelvic floor. Ann N Y Acad Sci. 2007;1101: 266-96. doi: 10.1196/annals.1389.034.

12. Davis KJ, Kumar D, Wake MC. Pelvic floor dysfunction: a scoping study exploring current service provision in the UK, interprofessional collaboration and future management priorities. Int J Clin Pract. 2010;64(12):1661-70. doi: 10.1111/j.1742-1241.2010.02509.x.
13. Liapis A, Bakas P, Liapi S, Sioutis D, Creatsas G. Epidemiology of female urinary incontinence in the Greek population: EURIG study. Int Urogynecol J. 2010;21(2): 217-22. doi: 10.1007/s00192-009-1019-2.

14. Hatchett L, Hebert-Beirne J, Tenfelde S, Lavender MD, Brubaker L. Knowledge and perceptions of pelvic floor disorders among African American and Latina women. Female Pelvic Med Reconstr Surg. 2011;17(4):190-4. doi: 10.1097/SPV.0b013e318229dd5c.

15. Herbruck LF. Stress urinary incontinence: prevention, management, and provider education. Urol Nurs. 2008;28 (3):200-6. PMID: 18605513.

16. Liebergall-Wischnitzer M, Cnaan T, Hochner H, Paltiel O. Self-reported prevalence of and knowledge about urinary incontinence among community-dwelling Israeli women of childbearing age. J Wound Ostomy Continence Nurs. 2015;42(4):401-6.doi: 10.1097/WON.0000000000 000133.

17. Richter LA, Gutman RE, Tefera E, Estep A, Iglesia CB. Knowledge of erectile dysfunction and pelvic floor disorders among young adults: a cross-sectional study. Can J Urol. 2015;22(2):7715-9. PMID: 25891335.

18. Shah AD, Shott S, Kohli N, Wu JM, Catlin S, Hoyte L. Do racial differences in knowledge about urogynecologic issues exist? Int Urogynecol J Pelvic Floor Dysfunct 2008;19(10):1371-8. doi: 10.1007/s00192-008-0639-2.

19. Guillemin F, Bombardier C, Beaton D. Cross-cultural adaptation of health-related quality of life measures: literature review and proposed guidelines. J Clin Epidemiol. 1993; 46(12):1417-32. doi:10.1016/0895-4356(93)90142-n.

20. Beaton DE, Bombardier C, Guillemin F, Ferraz MB. Guidelines for the process of cross-cultural adaptation of self-report measures. Spine (Phila Pa 1976). 2000;25(24): 3186-91. doi: 10.1097/00007632-200012150-00014.

21. Davis LL. Instrument review: Getting the most from a panel of experts. Appl Nurs Res. 1992;5(4):194-7. doi: 10. 1016/S0897-1897(05)80008-4

22. Polit DF, Beck CT. The content validity index: are you sure you know what's being reported? Critique and recommendations. Res Nurs Health. 2006;29(5):489-97. doi: 10.1002/nur.20147.

23. Korkut A. Prolaps ve İnkontinans Bilgi Anketinin Türkçe versiyonu: kültürel adaptasyon, güvenilirlik ve geçerlilik. MSKÜ Sağlık Bilimleri Enstitüsü, Yüksek Lisans Tezi. 2019.

24. Toprak Celenay S, Coban O, Sahbaz Pirincci C, Korkut Z, Birben T, Alkan A, et al. Turkish translation of the Prolapse and Incontinence Knowledge Questionnaire: validity and reliability. Int Urogynecol J. 2019;30(12):218390. doi: 10.1007/s00192-019-03962-5.

25. Branch LG, Walker LA, Wetle TT, DuBeau CE, Resnick NM. Urinary incontinence knowledge among community dwelling people 65 years of age and older. J Am Geriatr 
Soc. 1994;42(12):1257-62. doi:10.1111/j.1532-5415. 1994.tb06507.x.

26. Kara KC, Çıtak Karakaya İ, Tunalı N, Karakaya MG. Reliability and validity of the Incontinence Quiz-Turkish version. J Obstet Gynaecol Res. 2018;44(1):144-50. doi: 10.1111/jog. 13469.

27. Doğan H, Özengin N, Bakar Y, Duran B. Reliability and validity of a Turkish version of the Global Pelvic Floor Bother Questionnaire. Int Urogynecol J. 2016;27(10): 1577-81. doi: 10.1007/s00192-016-3014-8.

28. Toprak Celenay S, Akbayrak T, Kaya S, Ekici G, Beksac S. Validity and reliability of the Turkish version of the Pelvic Floor Distress Inventory-20. Int Urogynecol J. 2012;23(8):1123-7. doi: 10.1007/s00192-012-1729-8.

29. Kaplan PB, Sut N, Sut HK. Validation, cultural adaptation and responsiveness of two pelvic-floor-specific qualityof-life questionnaires, PFDI-20 and PFIQ-7, in a Turkish population. Eur J Obstet Gynecol Reprod Biol. 2012;162 (2):229-33. doi: 10.1016/j.ejogrb.2012.03.004.

30. Koo TK, Li MY. A guideline of selecting and reporting intraclass correlation coefficients for reliability research. J Chiropr Med. 2016;15(2):155-63. doi:10.1016/j.jcm.
2016.02.012

31. Floyd FJ, Widaman KF. Factor analysis in the development and refinement of clinical assessment instruments. Psychol Assess. 1995;7(3):286-99. doi: 10.1037/1040-35 90.7.3.286.

32. Andresen EM. Criteria for assessing the tools of disability outcomes research. Arch Phys Med Rehabil. 2000;81(12 Suppl 2):S15-20. doi: 10.1053/apmr.2000.20619.

33. Ugurlu N, Karakaya MG, Çıtak Karakaya I, Subaşı Baybuğa M, Demir Uysal D, Acer N, et al. Turkish version of Kogan's old people scale: A validity and reliability study. Turk J Geriatr. 2011;14(2):145-53.

34. Mckay ER, Lundsberg LS, Miller DT, Draper A, Chao J, Yeh J, et al. Knowledge of pelvic floor disorders in obstetrics. Female Pelvic Med Reconstr Surg. 2019;25(6): 419-25. doi:10.1097/SPV.000000000000060 4.

35. Lyatoshinskaya P, Gumina D, Popov A, Koch M, Hagmann M, Umek W. Knowledge of pelvic organ prolapse in patients and their information-seeking preferences: comparing Vienna and Moscow. Int Urogynecol J. 2016;27(11):1673-80. doi: 10.1007/s00192-016-3018-4. 